\title{
PENERAPAN SERVICE LEARNING DALAM PEMBELAJARAN MATAKULIAH PEDAGOGIK PADA KURIKULUM PENDIDIKAN CALON GURU
}

\author{
St. Syamsudduha ${ }^{1}$, Nurjannah Yunus Tekeng ${ }^{2}$ \\ 1,2Fakultas Tarbiyah dan Keguruan UIN Alauddin Makassar \\ 1,2Kampus II: Jalan H.M. Yasin Limpo Nomor 36 Samata-Gowa \\ Email: st.syamsudduha@uin-alauddin.ac.id ${ }^{1}$, st.nurjannah@uin-alauddin.ac.id ${ }^{2}$
}

\begin{abstract}
Abstrak:
Artikel ini merupakan hasil kegiatan pengabdian kepada masyarakat. Fokus kegiatan ini adalah upaya menjembatani pembelajaran di LPTK dan sekolah dengan menggunakan model service learning. Model ini merupakan salah satu experiental learning yang memberikan pengalaman belajar dalam bentuk pemberian layanan kepada masyarakat. Ciri khas model ini adalah proses pembelajaran yang diintegrasikan dengan pengalaman lapangan dan adanya proses refleksi. Metode yang digunakan dalam kegiatan ini adalah metode partisipatoris dengan melibatkan madrasah mitra merumuskan dan menganalisis mengenai aset yang dimiliki dan kebutuhan sekolah yang sesuai dengan mata kuliah pedagogik. Hasil pengabdian menunjukkan bahwa model pembelajaran service learning dalam pembelajaran mata kuliah pedagogik memberi dampak pada penguasaan pengetahuan yang lebih baik. Hal ini disebabkan oleh pengalaman pengamatan langsung di sekolah terkait fenomena yang menjadi fokus teori. Selain itu kemampuan berpikir kritis dan analitis juga lebih terlatih melalui proses refleksi. Hal lain yang juga berkembang dengan baik, adalah sikap peduli dan kepekaan terhadap masalah di sekolah.
\end{abstract}

\begin{abstract}
:
This article is the result of community service activities. The focus of this activity is the effort to bridge learning in LPTK and schools by using service learning model. This model is one of the experiential learning, which provides a learning experince in the form of community service. The characteristics of this model is the learning process that is integrated with experience and reflection. The method used in this activity is a participatory method involving partner madrasah to formulate and analyze potential assets and school needs based on pedagogic courses. The result of community service shows that service learning model in the pedagogical course has an impact on better knowledge mastery. This is due to the direct observation's experience in the school. In addition, critical thinking and analytical skills are also better trained through the process of reflection. The other things that also developed well are the caring attitude and sensitivity on problems in school.
\end{abstract}

\section{Kata kunci: \\ Service Learning, Refleksi, Teori dan Praktek}

PERAN perguruan tinggi dalam kehidupan sosial kemasyarakatan menjadi salah satu isu kontemporer saat ini. Perguruan tinggi diibaratkan menara gading yang hanya mengajarkan teori-teori yang sulit diaplikasikan secara langsung untuk menjawab masalah-masalah yang ada di dalam masyarakat. Penelitian yang dihasilkan hanya 
sebatas dokumen ilmiah, seakan tidak berdampak langsung bagi perbaikan kualitas hidup masyarakat. Hal inilah yang melatarbelakangi beberapa universitas terkemuka di beberapa negara maju melakukan perubahan model pembelajaran di perguruan tinggi seperti di Michigan State University (MSU) dan Easthern Michigan University (EMU) (presentasi Ethan Lowenstein (EMU) pada tanggal 8 Maret 2016 dan Corey Drake (MSU) pada tanggal 4 Pebruari 2016).

Perubahan model pembelajaran tersebut antara lain terlihat dari hasil Investigasi yang dilakukan di MSU dalam rangka kegiatan University Connect terkait preservice teacher practicum yang difasilitasi oleh USAID Prestasi. Perubahannya antara lain pada pelaksanaan pendidikan calon guru di MSU lebih menekankan pada pembelajaran melalui praktik lapangan. Mahasiswa diberi kesempatan untuk belajar dan menemukan sendiri konsep pendidikan dan pembelajaran melalui praktik di sekolah dan interaksi dengan masyarakat dimana siswa berada. Dosen tidak disebut sebagai lecturer tetapi course instructor untuk mempertegas peran dosen sebagai fasilitator dan mediator dalam mengantar mahasiswa menuju konsep yang sesuai. Kegiatan yang diberikan diramu dalam bentuk penugasan baik di Universitas maupun ketika praktik di sekolah. Penugasan yang terkait dengan praktik lapangan yaitu service learning, child study, coteaching dan lead teaching.

Selanjutnya pelaksanaan perkuliahan di College of Education MSU misalnya, semuanya didekatkan dengan konteks masyarakat. Pada tahun pertama dan kedua, semua matakuliah yang masuk dalam kelompok liberal art disertai dengan tugas service learning. Mahasiswa harus memahami konteks masyarakat sebelum menerima matakuliah kependidikan. Konteks masyarakat yang dimaksud, antara lain belajar mengenai perbedaan individu, cara setiap individu belajar, cara seorang anak belajar dari masyarakat dimana mereka tumbuh, dan pola interaksi dalam masyarakat dimana seorang anak tumbuh. Untuk dapat melakukan tugas tersebut, seorang mahasiswa melakukan proses interaksi dengan satu orang siswa dan masyarakat dimana siswa tersebut tinggal (dikenal dengan model one on one).

Salah satu contoh penerapan Service learning ini terlihat pada tugas yang diberikan kepada mahasiswa calon guru pada mata kuliah TE 250 (Human Diversity, Power, $\mathcal{E}$ Opportunity in Social Institutions). Tujuan mata kuliah ini adalah untuk memberi pemahaman kepada calon guru tentang bagaimana sekolah dan ketidaksetaraan sosial mempengaruhi satu sama lain, bagaimana konstruk kategori sosial terbentuk dan mempengaruhi individu. Kegiatan yang dilakukan selama 1 semester adalah melakukan diskusi di kelas terkait dua hal tersebut dan melakukan kegiatan lapangan 2 jam perminggu. Setelah kegiatan observasi dalam bentuk interaksi one on one dengan satu anak di sekolah atau di masyarakat yang berbeda dengan mereka secara agama atau ras, mahasiswa menulis sebuah final reflective paper dan mempresentasikan keterkaitan antara pengalaman di masyarakat dan bacaan mereka terkait konsep tentang gender, ras, bahasa, orientasi seksual, strata sosial, dan kemampuan/disabilitas/pendidikan khusus. Mahasiswa kemudian mendapatkan umpan balik untuk penyempurnaan tugas akhir. 
Pemberian tugas tidak hanya sekadar menunjukkan kemampuan akademik dalam tulisan, tetapi tugas yang diberikan juga memberikan pengalaman yang variatif. Sebagai contoh, mahasiswa dimotivasi untuk berinteraksi dengan siswa yang berbeda dengan mereka untuk mendapatkan pengalaman yang lebih bervariasi, karena ketika mereka ditempatkan dalam tugas menjadi real teacher, besar kemungkinan mereka bertemu dengan siswa yang memiliki karakteristik atau latar belakang yang berbeda. Dengan pengalaman ini, diharapkan mereka dengan mudah dapat berinteraksi dengan siswa manapun. Dampak dari proses belajar seperti ini, terlihat dari kemampuan mahasiswa calon guru ketika melakukan praktik mengajar di sekolah. Mereka umumnya menunjukkan kinerja yang sangat baik. Ini terlihat dari hasil observasi penulis di beberapa sekolah yang dikunjungi.

Hal tersebut di atas, secara umum belum dilakukan oleh lembaga pendidik dan tenaga kependidikan (LPTK) di Indonesia. Penyajian matakuliah dalam bentuk penyajian teori di kelas dan kurang memberikan kesempatan secara langsung kepada mahasiswa untuk mengenal konteks masyarakat. Akibatnya, mahasiswa pada umumnya melaksanakan proses belajar secara mekanik, menghafalkan teori, tetapi tidak memahami untuk apa dia belajar teori tersebut. Selain itu mahasiswa tidak tahu bagaimana menerapkan teori atau konsep yang dipelajarinya.

Sejalan dengan hal tersebut, LPTK sebagai salah satu perguruan tinggi yang diberi amanah menyelenggarakan pendidikan penyiapan calon guru dan tenaga kependidikan di Indonesia, dituntut untuk menghasilkan calon guru yang mengetahui kebutuhan peserta didik dan masyarakat dimana dia akan mengajar. Oleh karena itu, pembelajaran di LPTK harus dapat memenuhi kebutuhan mahasiswanya akan pengetahuan dan pengalaman tetang apa yang akan dikerjakan setelah lulus nanti.

Salah satu cara yang dapat dilakukan adalah mengemas mata kuliah dengan model pembelajaran yang mendekatkan konteks masyarakat dengan pembelajaran di universitas. Model pembelajaran yang dapat memberi pengalaman belajar seperti itu antara lain model pembelajaran berbasis service learning, sebagaimana praktik baik yang dilakukan oleh MSU.

\section{MODEL PEMBELAJARAN DI LPTK}

Pada era sekarang ini, persoalan pendidikan penyiapan guru di Indonesia, menjadi pusat perhatian banyak kalangan. Ada beberapa hal yang menjadi penyebab, antara lain rendahnya kualitas guru di Indonesia. Berdasarkan data hasil UKG tahun 2012 rata rata hasil UKG nasional sebesar 47, dan 88\% guru di luar jawa berada di bawah rata rata nasional (BPSDMPK \& PMP-Kemdikbud, 2012). Rendahnya kualitas guru tersebut dipengaruhi oleh banyak faktor, salah satu diantaranya adalah faktor pendidikan guru di Indonesia yang belum menyiapkan guru sesuai dengan apa yang guru butuhkan. Hal tersebut didasarkan pada hasil refleksi terhadap program pendidikan guru yang selama ini dipraktikkan. Kegiatan pembelajaran di LPTK disajikan dalam bentuk penyajian matakuliah yang didominasi oleh pemberian konsep dan teori, dan belum banyak mengenalkan praktik pembelajaran secara ril di sekolah. Pe- 
ngalaman praktik pembelajaran dan realita sekolah hanya diberikan sekali selama program pembelajaran yaitu pada saat pelaksanaan PPL. Sehingga calon guru yang dihasilkan kurang mendapat pengalaman praktis tentang dunia sekolah.

Pada dasarnya di Indonesia sudah ada upaya untuk mengatasi hal tersebut. Kemendikbud sebagai kementerian yang pernah menangani pendidikan guru telah menerbitkan beberapa peraturan tentang pengembangan lembaga pendidikan guru antara lain peraturan mengenai pengembangan kurikulum pendidikan tinggi yang mengacu pada kerangka kualifikasi Nasional Indonesia (KKNI) dan penyelenggaraan Pendidikan Profesi Guru (PPG) bagi guru prajabatan. Pada pengembangan kurikulum yang mengacu pada rumusan KKNI dan standar kompetensi guru Indonesia, salah satu hal yang ditawarkan adalah program pengembangan keahlian dalam pendidikan akademik LPTK yaitu dengan memasukkan program magang 1, 2 dan 3 dan memindahkan kegiatan praktik pengalaman lapangan ke program PPG.

Magang 1, bertujuan membangun landasan jati diri pendidik dan memantapkan kompetensi akademik kependidikan melalui: pengamatan langsung kultur sekolah, pengamatan untuk membangun kompetensi dasar pedagogik, kepribadian, dan sosial, pengamatan untuk memperkuat pemahaman peserta didik, pengamatan langsung proses pembelajaran di kelas, refleksi hasil pengamatan proses pembelajaran. Magang 1 diberikan bobot setara dengan 1 sks.

Magang 2, bertujuan memantapkan kompetensi akademik kependidikan dan kaitannya dengan kompetensi akademik bidang studi dan memantapkan kemampuan awal calon guru mengembangkan perangkat pembelajaran melalui: menelaah kurikulum dan perangkat pembelajaran yang digunakan guru, menelaah strategi pembelajaran, menelaah sistem evaluasi, merancang Rencana Pelaksanaan Pembelajaran (RPP), mengembangkan media pembelajaran, mengembangkan bahan ajar, mengembangkan perangkat evaluasi. Magang 2 diberikan bobot setara dengan 1 sks.

Hasil magang 2 selanjutnya digunakan untuk menyiapkan kemampuan awal proses pembelajaran dengan merasakan langsung mengajar pada bidang-bidang tertentu dalam waktu yang terbatas dengan menjadi "asisten guru" pada magang 3. Misalnya: mencoba mengajar dengan bimbingan melekat guru dan dosen pembimbing dengan tujuan merasakan langsung proses pembelajaran, pemantapan jati diri pendidik bukan untuk keterampilan pembelajaran dan bukan PPL, melaksanakan tugas-tugas pendampingan peserta didik dan kegiatan ekstra kurikuler. Magang 3 diberikan bobot setara dengan 2 sks.

Hal yang disebutkan di atas telah diimplementasikan dalam lingkup terbatas, dan belum semua LPTK melaksanakan, karena banyaknya kendala. Ada beberapa hal yang menjadi kendala sehingga rancangan yang ditawarkan Kemendikbud dan Kemenristekdikti tersebut belum dilaksanakan. Pertama, belum adanya model yang dianggap sesuai dalam menghubungkan antara pembelajaran teori dan pengalaman praktis di sekolah. Kedua, belum ditemukannya pola kemitraan yang baik antara sekolah sebagai tempat mahasiswa mendapatkan pengalaman praktis dengan universitas sebagai tempat mahasiswa belajar tentang konsep dan teori pembelajaran. 


\section{MODEL PEMBELAJARAN SERVICE LEARNING}

Service learning merupakan salah satu bentuk implementasi dari experiential learning yang dikemukakan oleh John Dewey. Dia menyatakan, "give the pupils something to do, not something to learn; and the doing is of such nature as to demand thinking; learning naturally result" (Jenkins, Amelia, Sheehey, Patricia, 2009). Ini bermakna bahwa pembelajaran sebenarnya terjadi jika peserta didik secara aktif mengkonstruksi makna melalui pengalaman nyata yang terbimbing sehingga memungkinkan mereka mengembangkan kompetensi berpikir kritis melalui refleksi, dan pada saat yang sama mereka dapat berkontribusi kepada masyarakat sebagai perwujudan tugas kemasyarakatan mereka. Inilah yang membedakan model pembelajaran service learning dengan pembelajaran tradisional yang mengandalkan kegiatan belajar pasif dan pemindahan fakta melalui metode ceramah yang tidak menghasilkan pembelajaran yang bermakna dan membuat peserta didik tidak dapat menghubungkan antara dunia sekolah dan pengalaman lapangan di masyarakat (Deeley, 2015).

John Dewey berargumentasi bahwa pembelajaran yang efektif dapat terjadi melalui interaksi antara pengetahuan dan keterampilan dengan pengalaman. Oleh karena itu, dia menekankan aplikasi kecerdasan manusia melalui inkuiri dan penyelesaian masalah nyata. Pemikiran ini didasarkan pada dua prinsip teori pengalaman (theory of experience), yaitu bahwa manusia dipengaruhi oleh pegalamannya dan manusia lebih dapat beradaptasi melalui belajar dari pengalaman. Ini disebut sebagai prinsip kontinuitas (continuity). Akumulasi pengalaman belajar ini kemudian akan mempengaruhi potensi pengalaman masa depannya. Kontinuitas menggambarkan aspek pengalaman yang berkaitan dengan individu. Sebuah pengalaman yang sesuai akan memodifikasi orang yang memiliki pengalaman, dan kualitas pengalaman berikutnya (Lucas dan Frazier, 2014). Kontinuitas yang diharapkan adalah yang mendorong pertumbuhan, membangkitkan rasa ingin tahu, dan membawa seseorang ke tempat baru dan lebih kuat di masa depan. Prinsip kedua yaitu interaksi, dimana interaksi dibangun berdasarkan gagasan kontinuitas dan menjelaskan bagaimana pengalaman masa lalu berinteraksi dengan situasi sekarang dan menciptakan pengalaman individu saat ini (Aedo, 2002; Neill, 2005).

Selain Dewey, David Kolb juga memperkenalkan teori experiential learning. Kolb menyatakan bahwa belajar adalah proses dimana pengetahuan diciptakan melalui transformasi pengalaman, dan pengetahuan merupakan kombinasi dari mendapatkan dan mentransformasi pengalaman (Kolb, 2008; McLeod, 2013). Kolb juga mengemukakan bahwa belajar melibatkan akuisisi konsep-konsep abstrak yang dapat diterapkan secara fleksibel dalam berbagai situasi. Dalam teorinya, dorongan untuk mengembangkan konsep-konsep baru disediakan oleh pengalaman baru. Menurut Kolb, belajar yang efektif terlihat ketika seseorang berkembang melalui sebuah siklus dengan empat tahapan, yaitu: (1) memiliki pengalaman konkret diikuti oleh (2) pengamatan dan refleksi pada pengalaman yang mengarah ke (3) pembentukan konsep abstrak (analisis) dan generalisasi (kesimpulan) yang kemudian (4) digunakan untuk 
menguji hipotesis dalam situasi masa depan, menghasilkan pengalaman baru (McLeod, 2013).

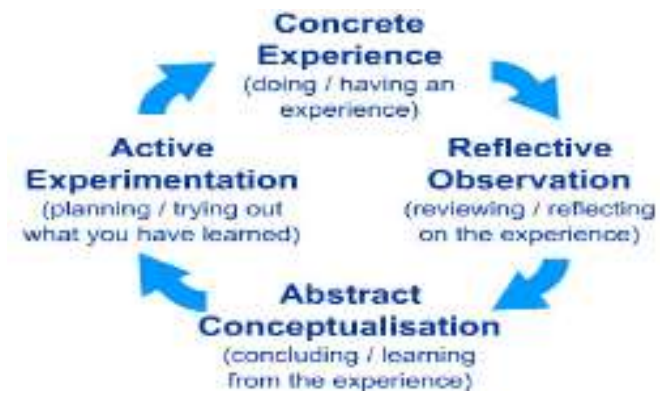

Gambar 1. Siklus experiential learning Kolb dengan empat tahapan belajar (Mcloud, 2013).

Vygotsky sebagai pelopor teori sosial konstruktivisme meyakini bahwa indivi$\mathrm{du}$ berada pada tingkat perkembangan tertentu dan memiliki potensi untuk perkembangan lebih lanjut (dikenal dengan konsep Zona perkembangan proksimal). Oleh karena itu, pendidikan seharusnya memberikan kesempatan kepada peserta didik untuk berkembang dalam zona perkembangannya. Vygotsky menjelaskan bahwa belajar diasumsikan bersifat sosial, yaitu bahwa anak-anak berkembang dalam kehidupan intelektualnya sebagai hasil interaksi dengan lingkungan sosialnya. Vygotsky menekankan pentingnya pengaruh lingkungan sosial terhadap perkembangan manusia. Ide ini terefleksi dalam model pembelajaran service learning yang menfasilitasi saling keterkaitan antara studi akademik dan praktik pengalaman pengabdian masyarakat serta adanya kegiatan proses dialog melalui kegiatan refleksi. Dengan mengakomodir interaksi antara kedua komponen tersebut, service learning memungkinkan adanya interaksi antara konsep abstrak dan internal peserta didik dengan materi dunia luar (nyata). Selain itu, eksposur terhadap berbagai macam situasi dalam pembelajaran service learning akan menghasilkan peningkatan kesadaran diri peserta didik dan selanjutnya perubahan perilaku dan tindakannya akan memiliki efek potensial terhadap perubahan dalam masyarakat. Ini berarti bahwa service learning memiliki efek transformatif tidak hanya pada individu, tetapi juga masyarakat (Deeley, 2015).

Teori konstruksi sosial juga bagian penting dari kerangka teoritis model pembelajaran service learning. Dalam hal ini adalah gagasan konstruk teori personal, yaitu berkaitan dengan bagaimana individu memahami atau memaknai pengalaman personal mereka. Sebagaimana tujuan peserta didik yaitu mengkonstruksi makna dari kombinasi antara pengalaman dan studi akademik mereka melalui kegiatan refleksi kritis (Ross dan Lott, t.th). Dalam prosesnya, mereka mungkin menantang dan merekonstruksi asumsi mereka tentang diri mereka sendiri dan pemahamannya terhadap dunia.

Ada empat model yang dapat digunakan dalam pembelajaran dengan service learning (dikutip dari Sturzl Center for Community Service E Learning), yaitu sebagai berikut: 
1. Placement Model, yaitu kegiatan service learning dimana mahasiswa ditempatkan atau memilih sendiri masyarakat dan bekerja sama dengan klien selama satu semester. Pelayanan yang diberikan oleh mahasiswa akan menjadi alat atau media pembelajaran. Mahasiswa mendapat akses dari populasi atau isu yang berkaitan dengan mata kuliah mereka yang selanjutnya memberikan bantuan yang diperlukan masyarakat. Mahasiswa dapat ditempatkan pada satu lokasi yang sama atau lokasi yang berbeda bergantung kepada struktur mata kuliah.

2. Presentation Model, yaitu kegiatan service learning dimana mahasiswa bekerja dalam kelompok kecil dan membuat materi presentasi dari materi kuliah dan mempresentasikannya kepada masyarakat atau kelompok yang membutuhkan informasi tersebut. Sebelum ke lapangan, pembimbing mata kuliah meminta mahasiswa untuk mempresentasikannya terlebih dahulu di kelas untuk mendapatkan umpan balik. Contoh topik presentasi dapat berupa peningkatan kesadaran terkait nutrisi, lingkungan, keberagaman, dan lain-lain.

3. Product Model, yaitu kegiatan service learning dalam bentuk aplikasi pengetahuan mahasiswa yang didapatkan di kelas untuk membuat produk (seperti video, brosur, website, dll.). Produk ini kemudian diberikan kepada masyarakat dengan tujuan tertentu. Mahasiswa dapat bekerja dalam kelompok kecil untuk mengembangkan produk atau dalam bentuk produk kelas untuk masyarakat yang dipilih.

4. Project Model, yaitu kegiatan service learning berupa kolaborasi mahasiswa dengan masyarakat untuk mengimplementasikan sebuah projek yang terintegrasi dengan materi perkuliahan tertentu dan memenuhi kebutuhan masyarakat yang teridentifikasi.

\section{KARAKTERISTIK SERVICE LEARNING}

Berdasarkan definisi service learning yang dikemukakan sebelumnya, maka terdapat beberapa komponen penting dari service learning dan hubungan antara komponen tersebut menunjukkan karakteristik dari model pembelajaran ini. Adapun komponen-komponen tersebut adalah materi akademik, pengabdian masyarakat yang relevan, dan refleksi kritis. Selanjutnya hubungan ketiga komponen tersebut dapat dijelaskan sebagai berikut:

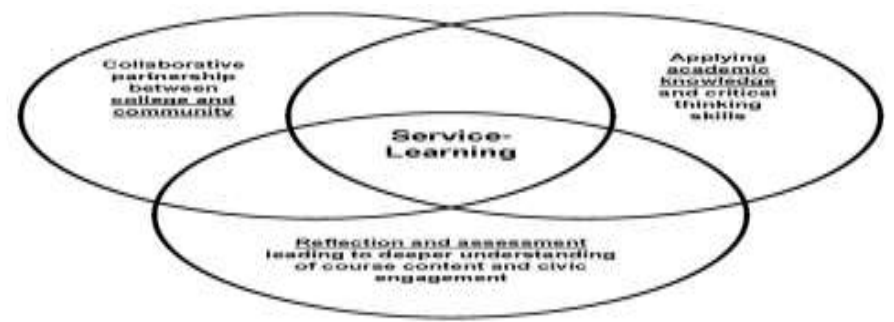

Gambar 1. Komponen model pembelajaran Service Learning (Center for Excellence in Learning Through Service (2004)

1. Service-learning merupakan kombinasi antara materi akademik dan pengabdian masyarakat. Kedua komponen ini harus saling berkaitan sehingga peserta didik dapat memberikan pelayanan yang berarti pada masyarakat yang menfasilitasi mereka dengan pengalaman yang berhubungan dengan materi akademik. 
2. Refleksi dalam service learning menghubungkan antara materi akademik dan pengalaman pengabdian masayarakat atau menghubungkan antara teori dan praktek. Oleh karena itu, melalui desain pembelajaran yang meliputi refleksi kritis, siswa meneliti pengalaman mereka secara kritis dan mengartikulasikan hasil belajar yang spesifik, sehingga meningkatkan kualitas pembelajaran dan pengabdian mereka.

3. Service learning adalah strategi pembelajaran kolaboratif. Sehingga mempersyaratkan adanya kerja sama (kemitraan) antara universitas dan masyarakat. Kemitraan (partnership) ini bersifat mutual dan resiprokal sehingga mempromosikan peningkatan akademik, perkembangan personal dan keterlibatan dalam masyarakat bagi peserta didik dan juga pemenuham kebutuhan masyarakat.

\section{METODE PENGABDIAN}

Fokus pengabdian yang dilakukan dalam kegiatan ini adalah pengembangan model pembelajaran berbasis service learning (SL) di salah satu LPTK (identitas disamarkan). Harapannya kegiatan pengabdian ini dapat menunjukkan salah satu alternatif model pembelajaran di LPTK. Untuk mencapai hal tersebut kegiatan pengabdian ini dilakukan dengan pendekatan partisipatoris yang melibatkan masyarakat (warga sekolah) untuk merumuskan bersama hal-hal yang menjadi kebutuhan untuk meningkatkan kualitas layanan sebagai lembaga pendidikan. Adapun gambaran mengenai metode yang digunakan adalah sebagai berikut:

\section{Aset mapping/ pemetaan aset awal/ analisis kebutuhan}

Pemetaan aset awal ini meliputi aset LPTK sebagai perguruan tinggi penyelenggara kegiatan service learning dan aset madrasah mitra sebagai lokasi kegiatan pelayanan. Kegiatan ini dapat digambarkan sebagai berikut:

a. Analisis pelaksanaan SL yang telah dilaksanakan oleh beberapa dosen. Analisis ini dilaksanakan dengan mengkaji dokumen modul service learning yang telah diterbitkan oleh Lembaga Penjaminan Mutu (LPM), dan mengumpulkan data pelaksanaan service learning yang telah dilakukan dosen di LPTK tersebut.

b. Analisis terkait mata kuliah pedagogik yang akan dikembangkan dengan menggunakan model service learning. Analisis ini dilakukan dengan memetakan kemungkinan penerapan prinsip-prinsip dan karakteristik service learning pada mata kuliah pedagogik, dan mempertimbangkan kebutuhan madrasah mitra. Kebutuhan madrasah akan dijadikan fokus penugasan dalam mata kuliah pedagogik berbasis service learning.

c. Pemetaan aset madrasah mitra, meliputi aktivitas pengamatan, analisis dokumen terkait sumber daya yang dimiliki madrasah mitra, dan diskusi bersama unsur kepala sekolah, guru dan pembina pesantren. Kegiatan ini dilaksanakan dalam rangka perumusan fokus pelayanan yang akan diberikan terkait mata kuliah pedagogik.

\section{Desain Pelaksanaan Service Learning}


a. Mendesain model pembelajaran yang akan diterapkan dan diintegrasikan dalam kegiatan akademik perkuliahan. Kegiatan ini dikemas dalam bentuk perencanaan pembelajaran mata kuliah beserta bentuk penugasan dan penilaiannya. Kegiatan ini melibatkan 2 orang dosen pengabdi.

b. Mendesain pola orientasi dan materi orientasi yang ditujukan ke guru dan kepala madrasah mitra, terkait pelaksanaan pembelajaran berbasis service learning. Kegiatan ini melibatkan 2 orang dosen pengabdi dan 1 orang dosen yang pernah mengikuti pelatihan service learning.

c. Mendesain pola orientasi dan materi orientasi yang ditujukan ke mahasiswa, terkait teknik pendampingan, case study, keterampilan mengamati dan etika interaksi. Kegiatan ini dilakukan oleh dosen pengabdi.

\section{Pelaksanaan Service learning}

a. Orientasi service learning pada guru dan mahasiswa. Kegiatan ini melibatkan 2 orang dosen, 4 orang guru dan 12 orang mahasiswa. Pada kegiatan ini dosen pengabdi menjelaskan isu dan fokus kegiatan, mengenalkan konsep service learning dalam proses pembelajaran. Pada kegiatan ini dosen, mahasiswa dan guru mencermati tahapan pembelajaran dan mengkaji kondisi aktual sekolah sesuai dengan bidang mata kuliah pedagogik yang diikuti mahasiswa. Untuk mendukung pelaksanaan tugas mahasiswa dan guru, diberikan pelatihan keterampilan mengamati, menyimak dan melakukan refleksi dan menuliskannya.

b. Pelaksanaan model pembelajaran service learning dengan mengintegrasikannya beberapa strategi pembelajaran dalam proses penyajian mata kuliah dan penugasan di madrasah.

c. Pelaksanaan penilaian dan refleksi dengan melibatkan mahasiswa dan guru madrasah. Pada tahap ini mahasiswa dapat menemukan konsep/teori dari hasil refleksi, dan guru dapat belajar dari proses yang dilalui dan hasil refleksi mahasiswa.

d. Peninjauan desain pembelajaran beserta penugasan tahap 1 .

e. Pelaksanaan proses penyajian mata kuliah dan penugasan di madrasah tahap 2.

f. Pelaksanaan penilaian dan refleksi dengan melibatkan mahasiswa dan guru madrasah tahap 2. Pada tahap ini mahasiswa dapat menemukan konsep/teori dari hasil refleksi, dan guru dapat belajar dari proses yang dilalui dan hasil refleksi mahasiswa.

g. Melakukan kegiatan ekpose hasil pengabdian dihadapan dosen matakuliah sejenis (Psikologi dan Perkembangan Peserta Didik) dan pimpinan LPTK tersebut (Dekanat, Ketua dan Sekeretaris Jurusan) untuk menerima penilaian dan mendiskusikan kemungkinan penerapan model pembelajaran ini dalam kurikulum Fakultas.

h. Melakukan seminar hasil pengabdian di hadapan masyarakat (warga sekolah) untuk menyampaikan produk berupa profil belajar beberapa orang siswa, dan 
menerima masukan terkait pelaksanaan perkuliahan dengan model service learning. Selain itu juga untuk mendiskusikan kemungkinan penerapan model pembelajaran ini dalam pembelajaran di sekolah.

i. Sharing Knowledge

Setelah ditemukan produk sesuai dengan yang diharapkan, maka akan dilakukan sharing knowledge dalam bentuk sebagai berikut:

1) Diseminasi dalam lingkup LPTK Sukses. Kegiatan ini dimaksudkan agar dosen lainnya dapat melihat keunggulan pelaksanaan pembelajaran berbasis service learning dan melihat kemungkinannya diterapkan pada mata kuliah sejenis.

2) Sharing knowledge juga dilakukan pada guru-guru di sekolah mitra. Kegiatan ini diujicobakan pertama kali pada proses perkuliahan dengan melibatkan guru dan kepala sekolah di sekolah mitra. Sebelum uji coba dilakukan, terlebih dahulu dilakukan orientasi/pengenalan service learning. Pada kegiatan ini guru bukan hanya mendapatkan informasi tentang service learning, tetapi juga dapat melihat kemungkinannya untuk diterapkan pada mata pelajaran di sekolah.

3) Bentuk lain yang dapat dilakukan adalah melalui publikasi hasil pengabdian kepada masyarakat ini pada jurnal ilmiah.

\section{HASIL PENGABDIAN}

\section{Gambaran Proses Pengembangan Model}

Kegiatan pengembangan model pembelajaran ini melalui beberapa proses/tahapan sebagai berikut:

a. Penetapan mata kuliah

Pada kurikulum LPTK tempat dimana kegiatan ini dilaksanakan, terdapat beberapa mata kuliah yang termasuk mata kuliah pedagogik. Mata kuliah ini termasuk dalam komponen Fakultas yang diharapkan dapat memberi bekal kemampuan pedagogik kepada mahasiswa. Pemilihan 1 mata kuliah disebabkan oleh keterbatasan waktu dalam menerapkannya. Proses penetapan dilakukan melalui rapat tim untuk menganalisis data mengenai pola service learning yang telah dilakukan oleh beberapa dosen, untuk memetakan kelebihan dan kekurangannya dengan cara membandingkannya dengan pola service learning yang dilaksanakan oleh beberapa universitas yang telah diobservasi sebelumnya (MSU dan WMU), serta beberapa sumber yang diperoleh dari jurnal ilmiah. Selanjutnya memilih 1 mata kuliah berdasarkan beberapa kriteria, antara lain; kemungkinan penerapan service learning, peta kemampuan guru (hasil UKG), kemampuan dosen pengabdi. Berdasarkan kriteria tersebut, maka ditetapkan mata kuliah yang akan dikembangkan adalah mata kuliah psikologi pendidikan dan perkembangan peserta didik. Mata kuliah ini dikemas dengan bobot sks 4 (3 SKS diformat dalam bentuk tatap muka dan 1 SKS diformat dalam bentuk magang di sekolah).

b. Penetapan madrasah mitra dan analisis kebutuhan 
Sebagai LPTK Sukses memiliki beberapa sekolah/madrasah mitra yang selama ini bekerjasama dalam menyelenggarakan praktik mengajar. Sekolah/madrasah mitra tersebut semuanya sudah terakreditasi minimal B.

Pada proses penetapan sekolah/madrasah yang dijadikan lokasi service learning, dipilih secara random sekolah/madrasah mitra tersebut. Madrasah yang terpilih adalah Madrasah Tsanawiyah dan Madrasah Aliyah Pondok Pesantren (identitas sekolah disamarkan) yang berlokasi di salah satu Kabupaten di Provinsi Sulawesi Selatan. Pesantren ini menyelenggarakan 3 tingkatan pendidikan, yaitu Madrasah Ibtidaiyah (MI), Madrasah Tsanawiyah (MTs), Madrasah Aliyah (MA). Tempat pelaksanaan pengabdian dalam kegiatan ini adalah adalah MTs dan MA.

Setelah proses pemilihan lokasi, selanjutnya dilakukan peta aset meliputi identifikasi kemampuan yang dimiliki dan kebutuhan sekolah mitra terkait persoalan pedagogik. Hasil pemetaan menunjukkan beberapa fakta sebagaimana tergambar pada tabel berikut.

Tabel 1. Keadaan Madrasah Aliyah Pondok Pesantren (tempat service learning berlaangsung) Tahun 2016/2017

\begin{tabular}{|l|c|c|c|l|}
\hline \multirow{2}{*}{ Jenis Data } & \multicolumn{2}{|c|}{ Jumlah } & \multirow{2}{*}{ Total } & Keterangan \\
\cline { 2 - 5 } & Laki-laki & Perempuan & 13 & $\begin{array}{l}\text { Tidak termasuk guru } \\
\text { pondok }\end{array}$ \\
\hline Guru & 3 & 10 & 84 & Tidak wajib mondok \\
\hline $\begin{array}{l}\text { Peserta } \\
\text { didik/Santri }\end{array}$ & 50 & 34 & - & $\begin{array}{l}\text { Pelayanan dilakukan } \\
\text { oleh pembina }\end{array}$ \\
\hline Guru BK & - & - & 10 & \\
\hline
\end{tabular}

Sumber Data: Kepala Sekolah MA (tempat service learning berlangsung) tgl 12 Oktober 2016

Berdasarkan data yang tergambar pada tabel 1 diketahui bahwa dari segi perbandingan jumlah guru dan peserta didik sudah proporsional, hanya saja belum terpenuhi dalam bidang-bidang tertentu, seperti ketersediaan guru BK.

Tabel 2. Keadaan Madrasah Tsanawiyah Pondok Pesantren (tempat service learning berlaangsung) 2016/2017

\begin{tabular}{|l|c|c|c|l|}
\hline \multirow{2}{*}{ Jenis Data } & \multicolumn{2}{|c|}{ Jumlah } & \multirow{2}{*}{ Total } & Keterangan \\
\cline { 2 - 5 } & Laki-laki & Perempuan & 11 & $\begin{array}{l}\text { Tidak termasuk } \\
\text { guru pondok }\end{array}$ \\
\hline Guru & 3 & 8 & 138 & Wajib mondok \\
\hline $\begin{array}{c}\text { Peserta } \\
\text { didik/Santri }\end{array}$ & 87 & 51 & - & $\begin{array}{l}\text { Pelayanan } \\
\text { dilakukan oleh } \\
\text { pembina }\end{array}$ \\
\hline Guru BK & - & - & & \\
\hline
\end{tabular}

Sumber Data: Kepala Sekolah MTs Pesantren (tempat service learning berlangsung) tgl 12 Oktober 2016 
Sama halnya dengan keadaan MA, berdasarkan data yang tergambar pada tabel 2 terlihat bahwa dari segi perbandingan jumlah guru dan peserta didik masih tergolong proporsional. Hanya saja belum terpenuhi dalam bidang-bidang tertentu, seperti ketersediaan guru BK. Padahal keberadaan guru BK, sangat diperlukan dalam penyediaan konsultasi masalah peserta didik.

Data-data tersebut selanjutnya dijadikan sebagai bahan pertimbangan dalam melihat kebutuhan madrasah. Kesimpulan yang diperoleh setelah melalui proses diskusi bersama pihak madrasah adalah sekolah tersebut membutuhkan informasi tentang profil belajar siswanya, karena umumnya mereka hanya memiliki profil yang sifatnya general dan belum ada profil yang sifatnya fungsional dan dapat digunakan guru dalam menentukan perencanaan pembelajaran dan aktivitas pembinaan di Pesantren. Beberapa data yang juga mendukung dalam pemilihan fokus pelayanan, adalah rasio jumlah guru dan siswa berdasarkan jenis kelamin yang tidak proporsional. Jumlah guru yang tidak proporsional ini berdampak pada aspek layanan yang bersentuhan langsung dengan kebutuhan siswa akan bimbingan kejiwaan khususnya terkait masalah-masalah yang mereka temukan dalam perkembangan kejiwaan selama berinteraksi di pesantren.

c. Proses perancangan perkuliahan dan instrumen pendukungnya

Kegiatan selanjutnya adalah menyusun silabus dan rancangan aktivitas perkuliahan serta bentuk orientasi yang akan diberikan kepada mahasiswa. Rancangan ini dikemas dalam bentuk silabus mata kuliah. Silabus ini mengalami beberapa kali perubahan seiring dengan proses refleksi yang dilakukan selama proses berlangsung. Perubahan tersebut antara lain tergambar sebagai berikut:

1) Pada desain awal, penyajian materi akan dilakukan setelah proses observasi awal mahasiswa. Hal ini didasarkan pada pertimbangan bahwa gambaran tentang peserta didik di sekolah akan menuntun mereka untuk mendapatkan konsep tentang peserta didik. Setelah melalui proses orientasi dengan mahasiswa dan melihat kemampuan awal mereka, akhirnya dilakukan perubahan desain. Desain awal juga belum memasukkan unsur service learning baik pada deskripsi maupun pada tujuan pembelajaran.

2) Desain selanjutnya, penyajian materi dilakukan secara bergantian, setiap materi disertai penugasan ke sekolah. Contohnya, penyajian materi pada minggu pertama (2 kali tatap muka) diikuti dengan penugasan observasi di sekolah, sehingga 14 kali pertemuan diselingi dengan 7 kali observasi sekolah. Ketika hal ini diujicobakan pada siklus pertama (2 kali tatap muka dan 1 kali observasi), ternyata pada proses interaksi antara mahasiswa dan siswa di sekolah tidak hanya mengungkap satu gejala yang mengarah pada dimensi belajar tertentu, tetapi gejala-gejala tersebut saling terkait satu sama lain. Hal ini kemudian membuat perubahan pada desain penyajian perkuliahan. Pada desain ini sudah memasukkan unsur service learning dalam deskripsi mata kuliah dan tujuan pembelajaran, kemudian memasukkan kegiatan refleksi sebagai bagian dari kegiatan pembelajaran. 
3) Desain terakhir yang dilaksanakan adalah dengan menyajikan materi kuliah secara runtut berdasar pada kelompok materi dan diantarai dengan observasi, kemudian menyiapkan penugasan mahasiswa dalam bentuk child study yaitu dengan strategi one on one. Pada penugasan ini mahasiswa di minta untuk melakukan observasi dan pengumpulan data terkait profil belajar peserta didik yang mencakup 5 dimensi belajar peserta didik. Pada penugasan ini, mahasiswa dilengkapi dengan pengenalan instrumen pengumpulan data sesuai dengan objek yang mereka temukan. Kegiatan observasi ini diselingi dengan refleksi yang dilakukan dalam dua bentuk yaitu refleksi yang sifatnya konfirmasi data dan konfirmasi teori. Konfirmasi data dilakukan di sekolah, sedangkan konfirmasi teoritis dilakukan di kampus. Kegiatan refleksi ini dilakukan secara individual, bersama teman satu kelompok dan bersama masyarakat (warga sekolah).

d. Pelaksanaan orientasi, perkuliahan berbasis service learning

Pelaksanaan kegiatan pengabdian berbasis service learning ini, didahului dengan pemberian orientasi kepada guru dan mahasiswa yang dilaksanakan pada tanggal 5 Nopember 2016. Materi orientasi meliputi: pengenalan kegiatan pengabdian masyarakat yang akan dilakukan, pengenalan konsep service learning sebagai model pembelajaran, dan latihan melakukan refleksi serta menuliskannya. Pada kegiatan ini, guru-guru mengapresiasi dengan banyak bertanya mengenai kemungkinan penerapan model ini pada mata pelajaran mereka.

Selanjutnya kegiatan perkuliahan dimulai pada tanggal 7 November 2016 setelah sebelumnya didahului dengan membuat kelas rekayasa yang terdiri dari 12 orang mahasiswa. Disebut dengan nama kelas rekayasa, karena kelas ini dibentuk oleh dosen pengabdi dengan merekrut mahasiswa dari 2 jurusan yaitu 6 mahasiswa dari jurusan Pendidikan Bahasa Inggris, dan 6 mahasiswa dari jurusan Pendidikan Biologi. Mahasiswa ini merupakan mahasiswa semester VII, yang dengan sukarela mau mengikuti kegiatan ini. Proses perkuliahan dilakukan dengan mengintegrasikan berbagai model pembelajaran, dan membiasakan mahasiswa untuk melakukan kegiatan membaca dan menulis hasil bacaan mereka terkait materi yang relevan. Pada kegiatan perkuliahan disajikan beberapa materi terkait perbedaan karakteristik peserta didik dalam belajar berdasarkan konsep dan teori belajar, perbedaan karakteristik individu berdasarkan teori perkembangan dan keterkaitan antara aspek-aspek perkembangan, dimensi profil belajar siswa, strategi pengumpulan data profil belajar siswa, konsep refleksi dan keterampilan melakukan refleksi dalam pembelajaran, keterampilan menyimak dan mengamati, keterampilan pemecahan masalah. Kegiatan perkuliahan ini awalnya diselingi observasi pada tanggal 9 November 2016, tetapi setelah melihat hasil yang dicapai, akhirnya diputuskan untuk menuntaskan materi terkait dasar teori mulai tanggal 10 November hingga 12 November, selanjutnya memulai observasi dan refleksi pada tanggal 14 November 2016. Pada kegiatan refleksi ini mahasiswa diantar melihat gejala yang mereka amati dari sisi teori kemudian belajar dari gejala tersebut dengan merefleksikan hasil pengamatan mereka. Kegiatan ini berlanjut hingga semua data 
terkait dimensi belajar terkumpul dan telah dilakukan refleksi bersama guru dan dosen pengabdi. Mahasiswa kemudian ditugaskan untuk merampungkan profil belajar dari peserta didik yang mereka amati dan selanjutnya secara berkelompok (satu kelompok terdiri 3 orang mahasiswa). Mereka memilih satu kasus yang menarik untuk ditampilkan pada kegiatan ekspose hasil service learning dengan menghadirkan guru dan pembina pesantren.

Ekpose hasil pengabdian berupa profil belajar dari 4 orang peserta didik, menginspirasi guru-guru untuk mengembangkan hal serupa dengan melengkapi profil belajar yang mereka miliki selama ini dengan tambahan data mengenai gaya belajar dan analisis mengenai faktor-faktor yang ikut berkontribusi terhadap gaya belajar peserta didik. Guru-guru juga mendapatkan tambahan pengetahuan dari dosen pengabdi tentang pemanfaatan profil belajar tersebut dalam penyusunan rancangan pembelajaran dan proses pembinaan di pesantren. Beberapa hal yang menarik muncul dalam diskusi, antara lain pertanyaan guru mengenai penerapan service learning, yang cenderung dilihat sebagai sebuah kegiatan pendampingan.

\section{Produk yang Dihasilkan}

a. Silabus

Silabus mata kuliah yang dikembangkan mencakup gambaran deskripsi mata kuliah dengan integrasi service learning, kompetensi dan indikator pencapaian, tugas, model refleksi, peta refleksi, Langkah-langkah kegiatan dan jadwal perkuliahan, strategi pembelajaran, penilaian, dan referensi bacaan topik-topik yang dikaji.

Silabus mata kuliah yang dikembangkan adalah silabus mata kuliah Psikologi dan perkembangan peserta didik dengan bobot sks 4 . Silabus ini dikembangkan dengan pendekatan service learning yang berfungsi menjembatani pembelajaran teori dan praktik, sekaligus memberi pengalaman kepada mahasiswa dalam memberi pelayanan kepada masyarakat.

Hal yang dikembangkan dan berbeda dari silabus mata kuliah sebelumnya, adalah kemasan materi, penyajian materi, penugasan, dan penilaian. Pengembangan ini melalui proses analisis kebutuhan (peta asset), desain, uji coba, refleksi dan revisi.

Kemasan materi terdiri dari pemberian pengetahuan dan keterampilan. Adapun materinya berisi teori-teori terkait karakteristik peserta didik, teori belajar, dan profil belajar peserta didik, tetapi juga pemberian pengetahuan dan keterampilan mengenai strategi pengumpulan data profil belajar, konsep refleksi dan keterampilan melakukan refleksi dalam pembelajaran, keterampilan mengamati dan menyimak, serta keterampilan pemecahan masalah.

Penyajian materi dalam bentuk perpaduan antara kegiatan tatap muka, observasi sekolah dan kegiatan refleksi. Pada kegiatan tatap muka, materi disajikan dalam bentuk pembelajaran mandiri dengan mengajak mahasiswa menelusuri dan menganalisis literature kemudian menyusunnya dalam berbagai bentuk kegiatan menulis seperti menyusun resume, makalah dan peta konsep. 
Pemberian penugasan juga dikemas dengan memadukan tugas dalam kegiatan tatap muka dan tugas ketika observasi sekolah. Semua penugasan ini diberikan dalam rangka mendukung pencapaian tujuan pembelajaran. Adapun jenis tugas utama yang dirancang dalam silabus ini adalah tugas child study, menulis dan presentasi.

Bentuk penilaian yang dikembangkan terdiri dari penilaian hasil belajar, penilaian proses, dan penilaian produk layanan. Penilaian hasil belajar meliputi penilaian pengetahuan (penguasaan mahasiswa terhadap teori-teori belajar), keterampilan dalam mengamati, menyusun laporan child study dan keterampilan presentasi, serta sikap positif mahasiswa. Penilaian proses melalui proses refleksi yang dilakukan mahasiswa, dan penilaian produk melalui kegiatan seminar hasil service learning.

b. Materi orientasi

Materi orientasi yang dimaksud adalah materi yang disusun oleh dosen pengabdi sebagai salah satu prasyarat dalam pelaksanaan perkuliahan berbasis service learning. Materi orientasi berisi pengenalan tentang konsep service learning, dan latihan menerapkan beberapa keterampilan dalam service learning, seperti keterampilan refleksi, pola interaksi guru, dosen dan mahasiswa dalam refleksi, dan pemahaman tentang gambaran mata kuliah psikologi dan perkembangan peserta didik. Hal yang dikembangkan dalam kegiatan orientasi ini, adalah peserta guru dan mahasiswa diberi pelatihan bersama, dan mereka diberikan kesempatan untuk melakukan simulasi bekerja bersama.

c. Format penugasan

Tugas utama adalah melakukan child study yaitu mahasiswa bekerja secara one on one dengan siswa untuk membuat/mengembangkan profil belajar siswa. Profil belajar ini mencakup lima dimensi penting (yaitu ciri biologis, performa akademik, pengaruh emosi dan sosial, preferensi belajar, faktor budaya dan sosial. Selain itu, mahasiswa juga diminta untuk membuat jurnal reflektif dan melakukan presentasi produk pengembangan profil belajar siswa.

d. Format Refleksi

Model refleksi dalam SL yang digunakan adalah kegiatan dimana mahasiswa terlibat dalam kegiatan komunitas yang bermanfaat, melakukan pengamatan, memaknai/menginterpretasi apa yang diamati, bertanya, mengkoneksikan apa yang dilihat di lapangan/sekolah dengan apa yang dipelajari dikelas, membuat teori, dan merencanakan tindakan, serta mencoba ide sendiri. Oleh karena itu, untuk mendukung efektivitas model refleksi, maka diterapkan empat prinsip yaitu kontinyu, menantang, dan kontekstual.

Refleksi disusun menggunakan peta refleksi (reflection map) yang tujuannya untuk menentukan kegiatan refleksi dalam konteks sosial atau dengan siapa mahasiswa berefleksi, dan menentukan kronologinya.

e. Format penilaian 
Penilaian dilakukan pada tiga domain yaitu kognitif (terkait penguasaan teori dan kemampuan dalam memformulasikan pengetahuan melalui observasi dan interaksi di sekolah), afektif (terkait sikap dalam proses perkuliahan dan kegiatan di sekolah meliputi sikap terhadap sesama mahasiswa, dosen, guru, dan siswa di sekolah, antusiasme, kesungguhan dalam melakukan investigasi dan tanggung jawab dalam melaksanakan tugas), dan psikomotor (terkait keterampilan proses dan keterampilan menyusun laporan case study serta keterampilan mempresentasikan.

f. Hasil Karya Mahasiswa

Hasil karya mahasiswa ini merupakan produk akhir dari pembelajaran dengan service learning. Produk ini adalah pengembangan profil belajar siswa yang berisi informasi tentang identitas siswa, metode pengumpulan data yang digunakan, analisis data dimensi profil belajar, dan usulan rekomendasi pembelajaran. Selain hasil karya dalam bentuk profil belajar siswa, juga terdapat hasil karya berupa jurnal reflektif dari mahasiswa.

\section{SIMPULAN}

Berdasarkan proses dan produk yang dihasilkan, dapat disimpulkan beberapa hal sebagai berikut:

a. Model service learning ini dapat diterapkan dalam matakuliah pedagogik

b. Pembelajaran yang memberi pengalaman secara langsung kepada peserta didik tentang konteks masalah memberi dampak yang sangat positif dalam pencapaian hasil belajar mahasiswa

c. Dampak pengiring dari kegiatan ini, adalah mahasiswa lebih mengenal konteks sekolah yang sebenarnya, dan dosen juga dapat menambah pengalaman mengenai masalah yang ada di sekolah.

d. Pengalaman melakukan refleksi bersama guru memberi pelajaran yang sangat berarti bagi dosen dan mahasiswa, khususnya dalam hal keterampilan menyimak dan berkomunikasi.

Berdasarkan temuan dan hasil refleksi yang dilakukan, ada beberapa rekomendasi yang disulkan yaitu:

a. Kepada pihak LPTK agar dapat mereplikasi kegiatan ini dalam skala yang lebih luas (pada kelas sesungguhnya) dengan jumlah mahasiswa yang lebih besar.

b. Menerapkan model service learning ini dalam penyajian mata kuliah psikologi pendidikan dan perkembangan peserta didik serta mengintegrasikannya dengan kegiatan magang 1 .

\section{DAFTAR PUSTAKA}

Aedo, C. (2002). The Value of Experience in Education: John Dewey.

Ahmed, Z., L. H., \& Plaut. (2008). Reflection in Higher Education Service-Learning. Scotts Valley, CA: Learn and Serve America's National Service-Learning Clearinghouse.

Center for excellence in Learning Through Service. (2004). Elements of Service Learning. Bearea 
College.

Deeley, S. J. (2015). Critical Perspectives on Service-Learning in Higher Education. New York: Palgrave McMillan.

Eyler, J., D. E. Giles Jr, et al. (1997). "The Impact of Service-Learning on College Students." Michigan Journal of Community Service Learning.

Farber, K. (2011). Change the World with Service Learning: How to Organize, Lead, and Assess Service-Learning Projects. Lanham: Rowman \& Littlefield Education.

Furco, A. (1996). Service-Learning: A Balanced Approach to Experimental Education, Corporation for National Service.

Jenkins. (2009). Implementing Service Learning in Special Education Coursework: What We Learned. Education, Vol. 129, No. 4.

Leon, A., \& McMahon, B. An Introduction To Service-Learning. Wahsinton: Office of Community Service, t.th.

Lucas, D \& Frazier B. (2014). The Effects of A Service-Learning Introductory Diversity Course on Pre-Service Teacher's Attitudes Toward Teaching Diverse Students Population. Academy of Educational Leadership Journal, Volume 18, Number 2.

McLeod, S. A. Kolb. (2013). Learning Styles. Retrieved from www.simplypsychology.org/learning-kolb.html.

Neill, J. (2005). John Dewey, the Modern Father of Experiential Education. Diakses dari Error! Hyperlink reference not valid.

Northern Illinois University, Faculty Development and Instructional Design Center. Diakses dari www.niu.edu/facdev pada tanggal 10 Desember 2016.

Ross, S., \& Lott, M., Guide to Academic Service-Learning. Community Based-Learning, Minnesota State University, t.th.

Sturzl Center for Community Service \& Learning. Academic Service-Learning. Faculty Handbook, t.th. 